\title{
Impacts of soil nutrient management practices on soil fertility, nutrient uptake, rice (Oryza sativa L.) productivity, and profitability
}

\author{
Reuben James Cillo Rollon*, Jay Mark Golis, Enrilou Salas \\ Department of Agricultural Sciences, Caraga State University, Butuan City, Philippines
}

\begin{tabular}{|c|c|}
\hline ARTICLE INFO & ABSTRACT \\
\hline $\begin{array}{l}\text { Article history: } \\
\text { Received on: August } 18,2020 \\
\text { Accepted on: October } 28,2020 \\
\text { Available online: March 10, } 2021\end{array}$ & $\begin{array}{l}\text { A field experiment was conducted at the experimental area of Caraga State University, Butuan City, the Philippines, to } \\
\text { determine the effects of different soil nutrient management practices on soil fertility, plant nutrition, productivity, and } \\
\text { rice profitability. There were six fertilizer management guidelines evaluated, namely: } \mathrm{T}_{1} \text {-Control, } \mathrm{T}_{2} \text {-Farmer's Fertilizer } \\
\text { Practice (FFP), } \mathrm{T}_{3} \text {-Soil-test-based (STB) fertilizer application, } \mathrm{T}_{4} \text {-Rice Crop Manager (RCM), } \mathrm{T}_{5} \text {-Organic Fertilizer+ }\end{array}$ \\
\hline $\begin{array}{l}\text { Key words: } \\
\text { Nutrient management, } \\
\text { Soil-test-based fertilizer, } \\
\text { Rice crop manager, } \\
\text { Rice productivity, } \\
\text { Rice profitability }\end{array}$ & $\begin{array}{l}\text { Nitrogen }(\mathrm{OF}+\mathrm{N}) \text {, and } \mathrm{T}_{6} \text {-sole } \mathrm{OF} \text {. Results showed that } \mathrm{OF} \text { and } \mathrm{OF}+\mathrm{N} \text { application substantially increased soil fertility after } \\
\text { harvest while } \mathrm{STB} \text { and } \mathrm{OF}+\mathrm{N} \text { increased tissue } \mathrm{N} \text { and } \mathrm{K} \text { uptake. } \mathrm{STB} \text { fertilizer application markedly increased grain yield } \\
\text { and profit by } 31 \% \text { and } 30 \% \text { over the control. In comparison, grain yield in the RCM and FFP increased by } 24 \% \text { and } 22 \% \text {. } \\
\text { Furthermore, profit increased by } 17 \% \text { and } 20 \% \text { in RCM and FFP, respectively. Further, the OF+N application boosted rice } \\
\text { productivity and profitability. The } \mathrm{OF}+\mathrm{N} \text { treatment increased the yield and profit by } 26 \% \text { and } 7 \% \text {. Conversely, the control } \\
\text { and the sole } \mathrm{OF} \text { treatments got the lowest yield and profits. Based on the results, STB treatment was the most productive } \\
\text { and profitable nutrient management practice with a } 4.95 \mathrm{t} / \text { ha yield and } \mathrm{P} 41,040.00 \text { net income. }\end{array}$ \\
\hline
\end{tabular}

\section{INTRODUCTION}

Rice is considered the most important agricultural commodity in the country. It is a primary dietary source of energy and protein for nearly 104.9 million Filipinos. In the country, rice continues to be the main growth driver of the Philippine economy, contributing about $350,132.00$ million pesos in the Gross Domestic Product [1]. The country's rice output for the past 5 years has slowed down with only a $1.3 \%$ increase in yield from 18.44 million metric tons (MT) in 2013 to 19.28 million MT in 2017 [1]. This is very low compared to other neighboring Asian countries (e.g., Thailand, Vietnam, and Indonesia).

Moreover, the rice production volume also declined for three successive years from 2014 up to 2016 [2]. Yield per hectare also dropped from 3.93 MT in 2017 to 3.87 MT in 2018. With the growing rice consumption and increasing population in the country, rice production must be increased significantly. However, up until now, rice-self-sufficiency is still a quest. The incapability to meet the need for increasing rice consumption is associated with relatively low yields, low cropping intensity, high post-harvest losses, and damage due to floods and typhoons. Furthermore, soil fertility reduction, continuous cropping without fertilizer application, and imbalance soil fertilization have contributed to the lower crop production.

\footnotetext{
*Corresponding Author

Reuben James Cillo Rollon,

Department of Agricultural Sciences,

Caraga State University, Butuan City, Philippines.

E-mail: rollonreubenjames@gmail.com
}

Soil fertility affects crop productivity/yield. Fertile soil supplies nutrients to plants without causing nutrients toxicity or deficiency or nutrient imbalance. Soil fertility and crop productivity can be increased through proper soil nutrient management (SNM), a process that optimizes the use of fertilizer (e.g., chemical fertilizer, compost, and animal manure) as a source of plant nutrients. SNM is aimed at improving soil health at the same time meeting the nutrient requirements of crops. This can be achieved by applying fertilizer in the right amount, using the right source, the correct placement, and proper timing [3]. Thus, SNM can maximize nutrient uptake to crops while minimizing nutrient losses.

Chemical (inorganic) and organic fertilizers (OFs) have been widely used by farmers to supplement soil nutrients. Chemical fertilizers are produced artificially to provide rapid nutrition to plants. Chemical fertilizers contain mineral nutrients in high concentrations (N, P, and K) that are soluble and readily plant-available. On the other hand, OFs are derived from animal manure and crop residues. OF application in soil offers several benefits such as building up soil organic matter, increases soil water holding capacity, reduces soil compaction, increases soil porosity, and improves soil structure [4-8].

Moreover, OF could boost soil microbial activity by providing an energy source to microorganisms and enhanced plant growth by providing a broad array of nutrients (macro and micronutrients) [9-12]. In general, OFs contain plant nutrients that are slowly available and at a low level. Thus, integrating chemical fertilizer with OF would bring more relevant improvement in soil fertility and crop productivity than applied solely $[13,14]$. The combined application of inorganic and 
OFs provides a balanced source of nutrients to plants and increases fertilizer use efficiency. Fertilizer application enriches soil nutrients, enhances nutrient uptake, and increases crop yield. However, improper fertilizer application, inappropriate timing, and application in excessive doses may lead to environmental degradation, reduces nutrient use efficiency, crop yield reduction, and profit loss. Therefore, proper SNM practices that consider the timing, quantities, and type of fertilizer can significantly maximize crop yield and profit.

A sound nutrient management program requires basic knowledge of the fertility status of the soil. Soil chemical test (a diagnostic tool for monitoring soil fertility) measures soil's nutrient level, which provides a basis for fertilizer recommendations. This nutrient management tool optimizes crop production, helps farmers develop a correct diagnosis of plant nutritional problems, avoids excessive use of fertilizer, minimizes nutrient losses, and saves farm inputs by applying only the actual amount of fertilizer required. Studies have shown that soil test-based fertilizer application increased crop yield and profit. Mittal and Sharma [15] reported higher grain and straw yield, nutrient uptake, and net return of rice over Farmer's fertilization practice and the control. Likewise, the application of fertilizers based on soil-test value significantly improved grain and straw yield of rice, soil nutrient contents, and soil microbial activities [16].

Another management approach to maximize crop production is the rice crop manager (RCM), a web-based generated site-specific nutrient recommendation. This crop and nutrient management tool were developed by the International Rice Research Center and Africa Rice Center for rice production. RCM already provided crop nutrient advisory to several countries such as India, Bangladesh, Indonesia, and the Philippines. In the Philippines, RCM was formally launched in 2013 and has already provided more than 1 million fertilizer recommendations to farmers. RCM recommendation provides an additional yield increase of $0.3-0.4 \mathrm{t} / \mathrm{ha}^{1}$ and added net income to about US\$ $100 \mathrm{ha}^{-1}$ per season [17]. In the study conducted by Sharma et al. [18], consistent higher yield was recorded in RCM recommendation compared to Farmer's filed practice and blanket fertilizer recommendation due to improved $\mathrm{N}$ management. The study involved 209 field trials in India for 2 years (covering two dry and two wet cropping seasons) involving different rice varieties in six agro-climatic zones.

Ensuring higher rice productivity requires appropriate nutrient management practices which have become an essential component of modern rice production technology [19]. Soil test-based fertilizer and $\mathrm{RCM}$ recommendations are among the right tools to aid farmers in making decisions related to nutrient management. Both tools provide field-specific fertilizer recommendations aimed to maximize both yield and profit. Conducting field trials to validate these tools' effectiveness will give additional information for future crop management decisions. In the study, we evaluated different fertilizer management practices (Farmer's Fertilizer Practice [FFP], soil-test-based [STB] fertilizer application, RCM, $\mathrm{OF}+\mathrm{N}$, and sole $\mathrm{OF}$ ) to determine its effects on soil fertility and nutrient uptake of rice. Further, the study aimed to identify the most productive and profitable nutrient management practices for rice production.

\section{MATERIALS AND METHODS}

\subsection{Site Description, Soil Collection, Preparation, and Analysis}

The study was conducted from March to July 2019 at the Rice Experimental Site $\left(8^{\circ} 57^{\prime} 07^{\prime \prime} \mathrm{N}, 125^{\circ} 35^{\prime} 53^{\prime \prime} \mathrm{E}, 27.7 \mathrm{~m}\right.$ above sea level) in Caraga State University (CSU), Butuan City, the Philippines. The site has a level topography with proper irrigation and had a history of rice farming for more than 10 years. The soil belongs to the Butuan series, classified as Typic Epiaquepts, had a loamy texture which was developed from older alluvial terraces of the Agusan River and poorly drained [20]. Further, Butuan City belongs to type IV climate, and rainfall is evenly distributed throughout the year. Butuan has a mean annual temperature of $26.8^{\circ} \mathrm{C}$ and a yearly rainfall of $2470 \mathrm{~mm}$. One month before the study commenced, 20 soil samples $(0-20 \mathrm{~cm}$ depth) were randomly collected from the experimental site for initial chemical analysis. The collected samples were air-dried, pulverized, sieved (2-mm mesh), and composited. A $1 \mathrm{~kg}$ samples were brought to the Regional Soils Laboratory, Butuan City, the Philippines for $\mathrm{pH}$, total organic carbon (OC), total N, extractable P, and exchangeable $\mathrm{K}$, $\mathrm{Ca}, \mathrm{Mg}$, and $\mathrm{Na}$ analysis. The result of the chemical analysis was the basis for fertilizer application in the STB treatment.

\subsection{Experimental Design and Treatment Details}

The experiment was arranged in a Randomized Complete Block Design with three replications. There were six fertilizer management guidelines evaluated in the study, namely: $\mathrm{T}_{1}$-Control, $\mathrm{T}_{2}-\mathrm{FFP}, \mathrm{T}_{3}-\mathrm{STB}$ fertilizer application, $\mathrm{T}_{4}-\mathrm{RCM}, \mathrm{T}_{5}-\mathrm{OF}+\operatorname{Nitrogen}(\mathrm{OF}+\mathrm{N})$, and $\mathrm{T}_{6}-$ sole $\mathrm{OF}$.

The FFP treatment (53-7-37 kg N, $\mathrm{P}_{2} \mathrm{O}_{5}$, and $\mathrm{K}_{2} \mathrm{O} / \mathrm{ha}$ ) was based on the current fertilization practice in $\mathrm{CSU}$ rice production. The chemical fertilizers were split applied into three: $1^{\text {st }}$ application at 21 days after transplanting (DAT) using two bags of urea (46-0-0); $2^{\text {nd }}$ application at 45 DAT using one bag of complete (14-14-14), and $3^{\text {rd }}$ application at 60 DAT using one bag of muriate of potash (0-0-60).

RCM recommendation (60-14-14 kg N, P2O5, and $\mathrm{K} 2 \mathrm{O} / \mathrm{ha}$ ) was generated using the RCM mobile android application. The recommendation was satisfied using two bags of complete fertilizer and two bags of urea. Complete fertilizer was applied at 21 DAT, while urea was applied at 45 DAT.

STB treatment (70-7-37 $\mathrm{kg} \mathrm{N}, \mathrm{P}_{2} \mathrm{O}_{5}$, and $\mathrm{K}_{2} \mathrm{O} / \mathrm{ha}$ ) was based on soil analysis performed at the Regional Soils Laboratory, Butuan City, the Philippines. Three split applications of fertilizers were made. The first application of fertilizer was made at 21 DAT using one bag of complete and 1.5 bags of ammonium sulfate (21-0-0). Second fertilizer application was made at 32 DAT using 2.25 bags of ammonium sulfate. The third fertilizer application was made at 45 DAT using 2.25 bags of ammonium sulfate and one bag of muriate of potash (0-0-60).

The $\mathrm{OF}+\mathrm{N}$ treatment was a combination of $80 \%(16 \mathrm{t} / \mathrm{ha})$ goat manure (GM), and 20\% (4 t/ha) carbonized rice hull (CRH) applied at $20 \mathrm{t} / \mathrm{ha}$ plus two bags of urea. The GM and CRH were obtained from the Organic Farm in CSU. Both organic amendments were broadcasted in the designated plot and immediately incorporated by hands 4 weeks before planting to allow mineralization of nutrients. On the other hand, urea was applied 15 DAT.

Sole OF treatment was a combination of $80 \%$ GM and $20 \% \mathrm{CRH}$ applied at $20 \mathrm{t} / \mathrm{ha}$ without chemical fertilizer (urea) addition. Both organic amendments were applied basally 4 weeks before transplanting. In addition, a control treatment was added where no fertilizer was applied.

\subsection{Land and Seedling Preparation}

The area was prepared by plowing and harrowing twice at weekly intervals using hand tractor. The field was leveled after the last harrowing, and three feet high ridges (levees) were constructed to avoid water and fertilizer movement. NSIC Rc122 (also known as Angelica 
variety), an inbred rice variety was used in the study. This variety has an average of $4.7 \mathrm{t} / \mathrm{ha}$ yield and resistant to blast and stem borer with intermediate reaction to bacterial blight, tungro, brown planthopper, and green leafhopper. The seeds were placed in a durable sack (halffilled) and soaked in clean water for $24 \mathrm{~h}$. After soaking, the water was drained, and the sack was placed on top of a wooden platform in a shaded area. The seeds were incubated for $24 \mathrm{~h}$ or until white "dots," or swollen embryos were observed. Raised seedbeds $(4-5 \mathrm{~cm}$ above the original soil level) were then prepared for rice seedlings. The seedbed was $1 \mathrm{~m}$ wide of any convenient length. A $40 \mathrm{~cm}$ spaces between seedbeds were provided to facilitate seedbed management. The sprouted seeds were grown in the seedbeds for 24 days and then transplanted in each experimental plot, which measures $4 \mathrm{~m}$ wide $\times 5 \mathrm{~m}$ length. A total of 1500 seedlings were planted in each plot ( 3 seedlings hill $^{-1}$ ) at a planting distance of $20 \mathrm{~cm} \times 20 \mathrm{~cm}$, respectively. Ten sample hills were selected per plot as an observational unit.

\subsection{Rice Management, Harvesting, Soil, and Plant Tissue Analysis}

After transplanting, the water in each plot was drained to facilitate root development and was re-irrigated seven DAT. Water in each plot was maintained at 5-inch depth throughout the growing period. Commercial herbicide and pesticides were used to control weeds and insect pests. Molluscicide was also used to control water snails infecting rice. Rice was harvested after reaching its maturity/harvesting stage (122 DAT). Ten representative hills were manually harvested per plot for data collection (plant height, tiller number, panicle weight, total number of grains panicle ${ }^{-1}$, total number of filled grains panicle ${ }^{-1}$, and $\%$ filled spikelet). The remaining hills were mechanically harvested using a combine harvester, and the yield data (grain yield and straw yield) were collected. Plant samples were collected after harvest and were sent to the laboratory for plant tissue analysis ( $\mathrm{N}$ and $\mathrm{K}$ ). Soil samples after harvest were also collected for residual analysis $(\mathrm{pH}$, total $\mathrm{OC}$, total $\mathrm{N}$, extractable $\mathrm{P}$, and exchangeable $\mathrm{K}$ ).

\subsection{Statistical Analysis}

Treatment means significance was determined through analyses of variance using Statistical Tool for Agricultural Research version 2.0.1 2014. If the significance is detected, a post hoc analysis was conducted and the differences between means were identified using Tukey's Honest Significant Difference Test.

\section{RESULTS AND DISCUSSION}

\subsection{Initial Soil Chemical Analysis}

Table 1 presents the initial analysis of the soil samples from the experimental field. Nutrient level in the area ranged from low to high. Soil $\mathrm{pH}$ was slightly acidic, with moderately low OC, low total $\mathrm{N}$, very high extractable $\mathrm{P}$, and sufficient exchangeable $\mathrm{K}, \mathrm{Na}, \mathrm{Ca}$, and $\mathrm{Mg}$.

\subsection{Chemical Composition of GM and CRH}

Chemical analysis of the two organic amendments used in the study showed that $\mathrm{GM}$ and $\mathrm{CRH}$ had alkaline $\mathrm{pH}(\mathrm{pH}>7.0)$ [Table 2]. The OC content in GM was 33-fold higher than CRH. Furthermore, GM had more top nutrient composition ( $\mathrm{N}, \mathrm{P}, \mathrm{K}$, and $\mathrm{Mg}$ ) than $\mathrm{CRH}$, except $\mathrm{Na}$ and $\mathrm{Ca}$. Superior nutrient concentrations in GM was probably related to animal diet. With high $\mathrm{pH}$ and $\mathrm{Ca}$ content, $\mathrm{CRH}$ may serve as an alternative liming material on acidic soil. On the other hand, GM could be an excellent source of nutrients, particularly in nutrientdepleted soil.
Table 1: Selected chemical properties of soil before the experiment

\begin{tabular}{lc} 
Property & Soil \\
$\mathrm{pH}$ & 6.19 \\
Total OC (\%) & 1.91 \\
Total N (\%) & 0.002 \\
Extractable P (ppm) & 27.00 \\
Exchangeable K (ppm) & 107.00 \\
Exchangeable Ca (ppm) & 502.00 \\
Exchangeable $\mathrm{Mg}(\mathrm{ppm})$ & 658.73 \\
Exchangeable $\mathrm{Na}(\mathrm{ppm})$ & 74.18 \\
\hline
\end{tabular}

OC: Organic carbon, N: Nitrogen

Table 2: Selected chemical properties of goat manure and carbonized rice hull

\begin{tabular}{lcc} 
Property & GM & CRH \\
$\mathrm{pH}$ & 7.43 & 10.46 \\
Total OC (\%) & 49.39 & 1.51 \\
Total N (\%) & 2.55 & 0.06 \\
$\mathrm{P}(\%)$ & 2.02 & 0.74 \\
$\mathrm{~K}(\%)$ & 3.31 & 1.07 \\
$\mathrm{Ca}(\%)$ & $\mathrm{BDL}$ & 0.34 \\
$\mathrm{Mg}(\%)$ & 1.81 & 2.47 \\
$\mathrm{Na}(\%)$ & 1.73 & 0.43 \\
\hline
\end{tabular}

OC: Organic carbon, BDL: Below the detection limit, GM: Goat manure, CRH: Carbonized rice hull, N: Nitrogen

\subsection{Impacts of SNM Practices on Soil Chemical Properties After Harvest}

\subsubsection{Soil $\mathrm{pH}$}

Nutrient management practice had a strong influence on soil $\mathrm{pH}$ after harvest [Table 3]. Soil pH in plots that received OF with or without inorganic $\mathrm{N}$ addition had slightly higher $\mathrm{pH}$ over the control treatment. Maximum $\mathrm{pH}$ of 6.65 was observed in the plots fertilized with $\mathrm{OF}+\mathrm{N}$, which was statistically at par with that in lone OF, RCM, and control. Higher $\mathrm{pH}$ in the organic plots may be attributed to the alkaline nature of CRH and GM [21,22]. In contrast, FFP and STB fertilizer applications decreased soil $\mathrm{pH}$. The largest dropped in $\mathrm{pH}$ (6.47) was observed in the STB treatment, where ammonium sulfate was used as a source of N. Oxidation of ammonium ions into nitrate (nitrification) during prolonged aerobic conditions in the soil may have led to $\mathrm{pH}$ reduction. Fageria et al. [23] reported a decreasing trend in $\mathrm{pH}$ with an increasing rate of ammonium sulfate and urea application. However, the ammonium sulfate application resulted in a greater magnitude of $\mathrm{pH}$ decrease than by urea. In general, the $\mathrm{pH}$ in all treatment plots was slightly acidic, which is suitable for tropical rice that grows in a wide $\mathrm{pH}$ range from 4 to 8 [24].

\subsubsection{Soil total OC}

OF application remarkably increased soil total OC after harvest [Table 3]. The most substantial increase was recorded in the sole OF treatment, with a $32 \%$ increase in OC over the control. Similarly, the $\mathrm{OF}+\mathrm{N}$ application increased soil $\mathrm{OC}$ content by $27 \%$. Meanwhile, a comparable increase in OC was noted in control, FFP, STB, and RCM treatments. The substantial rise in OC in the OF amended plots were attributed to high carbon inputs from GM. Animal manures are rich in labile (bio-available) form of carbon that rapidly decomposed in the soil. Based on the chemical analysis, GM contained $49.39 \%$ carbon. The total amount of carbon applied from GM was $7902 \mathrm{~kg} / \mathrm{ha}$. 
A similar increase in soil OC was reported by Putra et al. [25] with a GM application at 6 t/ha. Furthermore, Tayyab et al. [26] noted a substantial increase in soil total carbon with GM application. Higher soil carbon availability may be attributed to the rapid decomposition of soluble organic compounds from manure.

\subsubsection{Soil total nitrogen}

Soil $\mathrm{N}$ content, as presented in Table 3, follows a similar trend with OC. Total N ranged from $0.22 \%$ to $0.33 \%$, with the highest $\mathrm{N}$ increase $(50 \%)$ obtained in the sole OF treatment relative to the control. Combined $\mathrm{OF}+\mathrm{N}$ followed this with a $36 \%$ increase in N. Meanwhile, the plot that did not receive fertilizer (control) got the lowest $\mathrm{N}$ increase. Nitrogen content in the FFP, RCM, and STB treatments was statistically at par with the control. Lesser N content in the STB and FFP could partly be explained by plant $\mathrm{N}$ removal. Meanwhile, $\mathrm{N}$ enrichment in the $\mathrm{OF}$ and $\mathrm{OF}+\mathrm{N}$ treatment was probably due to $\mathrm{N}$-mineralization from manure. Mineralization occurs most readily when the C:N ratio of the material is low $(<24: 1)$ [27].

Moreover, a very strong positive correlation $(\mathrm{r}=0.86 ; P \leq 0.01)$ was observed between total $\mathrm{N}$ and soil organic OC [Table 4]. This indicates

Table 3: Means for the residual soil chemical properties of lowland rice as affected by soil nutrient management practices

\begin{tabular}{lccccc} 
Treatments & $\mathbf{p H}$ & $\begin{array}{c}\text { Total } \\
\mathbf{O C}(\%)\end{array}$ & $\begin{array}{c}\text { Total } \\
\boldsymbol{N}(\%)\end{array}$ & $\begin{array}{c}\text { Extractable } \\
\mathbf{P}(\mathbf{p p m})\end{array}$ & $\begin{array}{c}\text { Exchangeable } \\
\mathbf{K}(\mathbf{p p m})\end{array}$ \\
$\mathrm{T}_{1}=$ Control & $6.57^{\mathrm{ab}}$ & $1.86^{\mathrm{c}}$ & $0.22^{\mathrm{c}}$ & $17.67^{\mathrm{c}}$ & $159.33^{\mathrm{b}}$ \\
$\mathrm{T}_{2}=\mathrm{FFP}$ & $6.53^{\mathrm{ab}}$ & $1.95^{\mathrm{bc}}$ & $0.26^{\mathrm{bc}}$ & $15.33^{\mathrm{c}}$ & $136.33^{\mathrm{b}}$ \\
$\mathrm{T}_{3}=\mathrm{STB}$ & $6.47^{\mathrm{b}}$ & $2.07^{\mathrm{abc}}$ & $0.26^{\mathrm{bc}}$ & $14.67^{\mathrm{c}}$ & $143.00^{\mathrm{b}}$ \\
$\mathrm{T}_{4}=\mathrm{RCM}$ & $6.60^{\mathrm{ab}}$ & $1.93^{\mathrm{c}}$ & $0.26^{\mathrm{bc}}$ & $15.67^{\mathrm{c}}$ & $136.33^{\mathrm{b}}$ \\
$\mathrm{T}_{5}=\mathrm{OF}+\mathrm{N}$ & $6.65^{\mathrm{a}}$ & $2.36^{\mathrm{ab}}$ & $0.30^{\mathrm{ab}}$ & $34.67^{\mathrm{b}}$ & $296.67^{\mathrm{a}}$ \\
$\mathrm{T}_{6}=\mathrm{OF}$ & $6.60^{\mathrm{ab}}$ & $2.46^{\mathrm{a}}$ & $0.33^{\mathrm{a}}$ & $49.33^{\mathrm{a}}$ & $370.00^{\mathrm{a}}$ \\
\hline
\end{tabular}

Means in a column followed by common letters are not significantly different at $5 \%$ level of significance. FFP: Farmer's Fertilizer Practice, STB: Soil-test-based, RCM: Rice Crop Manager, OF: Organic fertilizer, OF + N: OF + Nitrogen, OC: Organic carbon that the addition of fresh carbon from manure might have stimulated soil microbial activity, which speeds up the rate decomposition and mineralization of nutrients from manure. Furthermore, OF applications may have increased the cation exchange capacity of the soil resulting in higher nutrient retention. Furthermore, organically bound nutrients such as in manure are not readily lost from the soil as it is being tied up in the carbon to carbon structure of the organic matter, hence increased availability of residual $\mathrm{N}$ in the soil. In contrast, $\mathrm{N}$ from chemical fertilizers is more soluble, leachable and prone to runoff losses, volatilization, and denitrification, particularly in paddy soils $[28,29]$. Similar results were reported by Uwah and Eyo [30] and Uwah et al. [31], who documented higher nutrient availability in soil with GM application. According to them, manure application may have stimulated microbial activity which hastens the decomposition of the organic forms of N, P, and K. Meanwhile, Cai et al. [32] reported a significant increase in soil OC and total $\mathrm{N}$ in bulk soil with long-term application of manure, with or without chemical fertilizer application.

\subsubsection{Soil extractable phosphorus}

The residual $\mathrm{P}$ content of the soil after harvest significantly increased with nutrient management [Table 3]. The plot treated with sole OF increased soil P by $179 \%$ over the control plot. This was followed by the $\mathrm{OF}+\mathrm{N}$ treatment with a $96 \%$ increase in $\mathrm{P}$. Meanwhile, the control, FFP, RCM, and STB treatments have the same comparable increase in soil $\mathrm{P}$. The massive increase in $\mathrm{P}$ with manure application may have been attributed to rapid P-mineralization. Animal manures are an excellent source of essential micro and macronutrients $(\mathrm{N}, \mathrm{P}$, and $\mathrm{K}$ ) which are necessary for normal growth and development of plants. Furthermore, it is noteworthy to mention that GM had a low C:P ratio of 24 . Organic materials with a low C:P ratio $(<200: 1)$ are rapidly mineralized, thus releasing more available nutrients to plants. Correlation analysis showed a strong positive relationship ( $\mathrm{r}$ $=0.79 ; P \leq 0.01)$ between soil extractable P and total OC [Table 4]. This indicates that soil $\mathrm{P}$ availability increases with increasing OC content. According to Hou et al. [33], soil OC provides energy and carbon structure for microbes which stimulate microbial activity,

Table 4: Pearson correlation matrix for the selected parameters

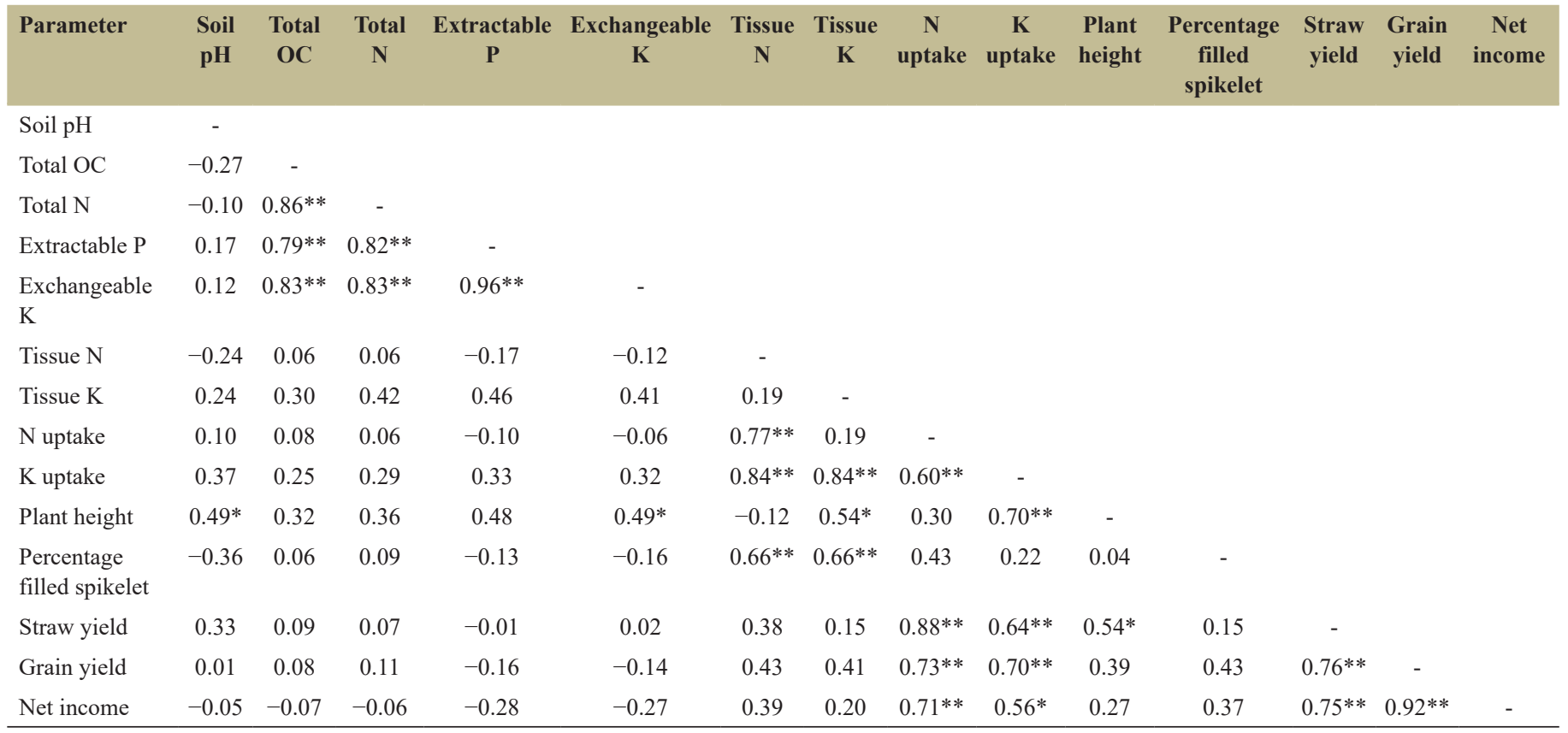

*Significant at $P<0.05, * *$ Significant $P<0.01$. OC: Organic carbon, N: Nitrogen 
leading to high production of phosphatase enzyme which aid in the mineralization of soil organic P. Significant increases in soil P with GM application has been well documented by Ojeniyi et al. [34]; Gichangi et al. [35]; and Kihanda et al. [36]. According to them, postharvest increase in soil fertility was due to the direct contribution of nutrients from manure. The results clearly showed that soil fertility and productivity in nutrient-depleted soil could be improved through manure application.

\subsubsection{Soil exchangeable potassium}

OF application markedly increased available soil $\mathrm{K}$ after harvest [Table 3]. Sole $\mathrm{OF}$ and combined $\mathrm{OF}+\mathrm{N}$ increased available soil $\mathrm{K}$ by $132 \%$ and $86 \%$, respectively, over the control. Meanwhile, the FFP, $\mathrm{STB}$, and RCM have the same comparable increase in soil $\mathrm{K}$ with the control. Potassium enrichment in the plot fertilized with OF may have been attributed to direct nutrient addition and mineralization of nutrients from manure. Correlation analysis between soil $\mathrm{K}$ and $\mathrm{OC}$ showed a very strong positive relationship $(\mathrm{r}=0.83 ; P \leq 0.01)$ [Table 4]. The correlation pattern indicated increasing soil $\mathrm{K}$ availability with increasing $\mathrm{OC}$ in the soil. Organic matter, which comprised $58 \%$ carbon, is one of the primary sources of nutrients in the soil which is released during mineralization. Rapid mineralization is favored by low substrate's $\mathrm{C}: \mathrm{N}$ ratio, neutral to alkaline soil $\mathrm{pH}$, warm temperature, moist soil, and high microbial population. The total amount of $\mathrm{K}$ applied in sole $\mathrm{OF}$ and combined $\mathrm{OF}+\mathrm{N}$ treatments was $573 \mathrm{~kg} / \mathrm{ha}$, which was 16-fold higher than $\mathrm{K}$ added in FFP and STB and 41-fold higher than RCM treatments. However, nutrient availability from manure is dependent on the rate of mineralization. A positive increase in the soil available $\mathrm{K}$ with manure application alone or in combination with chemical fertilizer has been reported by other workers $[13,37,38]$.

\subsection{Impacts of SNM Practices on Tissue $N$ and P Concentration of Rice}

Table 5 presents the $\mathrm{N}$ and $\mathrm{K}$ content in the above-ground plant parts of rice (straw) after harvest. Fertilizer management practices did not significantly influence nutrient concentration in rice. However, nutrient contents in plants applied with fertilizer were numerically higher than those in control. The $\mathrm{N}$ content varied from $0.69 \%$ to $0.92 \%$, which was below the optimal range $(2.8-3.6 \%)$ for rice [39]. Lower $\mathrm{N}$ concentration in the leaves may have been attributed to the remobilization of plant $\mathrm{N}$ from the leaves to panicles and grains during the reproductive stage $[40,41]$. In rice, $\mathrm{N}$ promotes grain fillings and improves protein content in grains.

Similarly, rice K content slightly increased with fertilizer application [Table 5]. The lowest $\mathrm{K}$ concentration was recorded in the control

Table 5: Means for the $\mathrm{N}$ and $\mathrm{P}$ tissue content and uptake of lowland rice as affected by soil nutrient management practices

\begin{tabular}{lcccc} 
Treatments & $\begin{array}{c}\text { N content } \\
(\%)\end{array}$ & $\begin{array}{c}\text { K content } \\
(\%)\end{array}$ & $\begin{array}{c}\text { N uptake } \\
(\mathbf{k g} / \mathbf{h a})\end{array}$ & $\begin{array}{c}\text { K uptake } \\
(\mathbf{k g} / \mathbf{h a})\end{array}$ \\
$\mathrm{T}_{1}=$ Control & 0.69 & 2.04 & $24.36^{\mathrm{b}}$ & $71.95^{\mathrm{b}}$ \\
$\mathrm{T}_{2}=\mathrm{FFP}$ & 0.77 & 2.22 & $40.37^{\mathrm{ab}}$ & $115.59^{\mathrm{ab}}$ \\
$\mathrm{T}_{3}=\mathrm{STB}$ & 0.92 & 3.22 & $46.66^{\mathrm{a}}$ & $164.20^{\mathrm{a}}$ \\
$\mathrm{T}_{4}=\mathrm{RCM}$ & 0.80 & 3.05 & $35.98^{\mathrm{ab}}$ & $135.93^{\mathrm{ab}}$ \\
$\mathrm{T}_{5}=\mathrm{OF}+\mathrm{N}$ & 0.74 & 3.74 & $38.90^{\mathrm{ab}}$ & $190.92^{\mathrm{a}}$ \\
$\mathrm{T}_{6}=\mathrm{OF}$ & 0.78 & 3.22 & $36.87^{\mathrm{ab}}$ & $150.54^{\mathrm{a}}$ \\
\hline
\end{tabular}

Means in a column followed by common letters are not significantly different at 5\% level of significance. FFP: Farmer's Fertilizer Practice, STB: Soil-test-based, RCM: Rice Crop Manager, OF: Organic fertilizer, OF + N: OF + Nitrogen treatment $(2.04 \%)$, while combined organic and inorganic fertilizer $(\mathrm{OF}+\mathrm{N})$ increased $\mathrm{K}$ content to $3.74 \%$. In general, $\mathrm{K}$ contents in plants were above the optimal range value of $1.5-2.7 \%$, except in the control and FFP treatments [39].

\subsection{Impacts of SNM Practices on Total N and P Uptake of Rice}

The $\mathrm{N}$ uptake of rice significantly increased with fertilizer management practices [Table 5]. The values went up from $24.36 \mathrm{~kg} \mathrm{~N} / \mathrm{ha}$ in control to $46.66 \mathrm{~kg} \mathrm{~N} / \mathrm{ha}$ in the STB management. The highest plant $\mathrm{N}$ accumulation was recorded in the STB practice, with a $92 \%$ increase in $\mathrm{N}$ over the control. Furthermore, the FFP and RCM treatments increased plant $\mathrm{N}$ uptake by $66 \%$ and $48 \%$, respectively. Similarly, higher $\mathrm{N}$ accumulation was recorded in the sole $\mathrm{OF}$ and $\mathrm{OF}+\mathrm{N}$ practice, which was statistically similar to control. Higher $\mathrm{N}$ uptake of rice with STB fertilizer application may be attributed to high application rates of $\mathrm{N}(70 \mathrm{~kg} / \mathrm{ha})$ and improved $\mathrm{N}$ use efficiency. Correlation analysis showed that $\mathrm{N}$ uptake was strongly associated with tissue $\mathrm{N}(\mathrm{r}=0.77$; $P \leq 0.01)$ and $\mathrm{K}$ uptake $(\mathrm{r}=0.60 ; P \leq 0.01)$ [Table 4]. The correlation suggests that plants with high tissue $\mathrm{N}$ content would accumulate more $\mathrm{N}$ in their biomass. Moreover, increasing levels of $\mathrm{K}$ in plant tissue stimulates $\mathrm{N}$ uptake. At optimum levels of nutrition, rice takes up about $6 \mathrm{~kg}$ of $\mathrm{N}$ in straw for every ton of grain yield [42]. In rice, $\mathrm{N}$ promotes rapid plant growth and tillering. Nitrogen also increases grain yield, grain filling, and quality of grains (protein content) [41,43,44].

Nutrient management significantly influenced $\mathrm{K}$ uptake in plants [Table 5]. The $\mathrm{K}$ uptake values ranged from $71.95 \mathrm{~kg} / \mathrm{ha}$ to $190.92 \mathrm{~kg} / \mathrm{h}$. The highest K uptake was recorded in the $\mathrm{OF}+\mathrm{N}$ practice with a $165 \%$ increase over the control. This was followed by STB and sole OF treatments with $128 \%$ and a $109 \%$ increase in K. Meanwhile, $\mathrm{K}$ uptake in FFP and RCM was statistically at par with that in control. Higher $\mathrm{K}$ accumulation in the $\mathrm{OF}+\mathrm{N}$ practice was probably due to the rise in soil available $\mathrm{K}$. Moreover, $\mathrm{K}$ uptake was strongly associated with $\mathrm{K}$ tissue $(\mathrm{r}=0.84 ; P \leq 0.01)$ and $\mathrm{N}$ uptake $(\mathrm{r}=0.60 ; P \leq 0.01)$ [Table 4]. Hence, greater $\mathrm{K}$ accumulation in the leaf was mainly due to an increase in tissue $\mathrm{K}$ and $\mathrm{N}$ uptake. Approximately $14 \mathrm{~kg}$ of $\mathrm{K}$ is absorbed in straw per ton of grain yield [45]. In rice, $\mathrm{K}$ promotes root growth, prevents the crop from lodging, and increases grain size and weight and grain fillings $[46,47]$. Thus, a deficiency of $\mathrm{K}$ would severely limit grain production, lower grain weight, and produced higher numbers of unfilled grains. The result of our study corroborates with the findings of Moe et al. [48], who reported higher N, P, and $\mathrm{K}$ uptake of rice with manure and chemical fertilizer application. Similarly, STB inorganic fertilizer application alone or integrated with organic manure significantly increased the total uptake of N, P, and K of rice plant [49].

\subsection{Impacts of SNM Practices on the Growth and Yield Components of Rice}

\subsubsection{Plant height at $45 \mathrm{DAT}$}

Table 6 presents the height of rice at 45 DAT as affected by fertilizer management practices. Tallest plant height was recorded in the $\mathrm{OF}+\mathrm{N}$ treatment, followed by OF and FFP. Meanwhile, shorter heights were observed in control, STB, and RCM treatments. Plant height is often found both as an indicator of growth and as a parameter used for environmental influences. Superior growth seen in the OF+ $\mathrm{N}$ treatment was attributed to the increase in soil available $\mathrm{K}$, plant tissue $\mathrm{K}$, and soil $\mathrm{pH}$ improvement [Tables 3 and 5]. Correlation analysis showed a moderate to strong positive correlation between plant height and soil $\mathrm{pH}(\mathrm{r}=0.49 ; P \leq 0.05)$, available $\mathrm{K}(\mathrm{r}=0.49$; $P \leq 0.05)$, tissue $\mathrm{K}(\mathrm{r}=0.54 ; P \leq 0.05)$, and total $\mathrm{K}$ uptake $(0.70$; 
Table 6: Means for the growth and yield components of lowland rice as affected by soil nutrient management practices

\begin{tabular}{|c|c|c|c|c|c|c|c|}
\hline Treatments & $\begin{array}{c}\text { Plant } \\
\text { height }(\mathrm{cm})\end{array}$ & $\begin{array}{c}\text { Tiller } \\
\text { number }\end{array}$ & $\begin{array}{l}\text { Average panicle } \\
\text { weight (g) }\end{array}$ & $\begin{array}{c}\text { Total panicle } \\
\text { weight } \text { hill }^{-1}(\mathrm{~g})\end{array}$ & $\begin{array}{l}\text { Tot. number of } \\
\text { grains panicle }^{-1}\end{array}$ & $\begin{array}{l}\text { Total number of filled } \\
\text { grains panicle }^{-1}\end{array}$ & $\begin{array}{c}\text { Percentage } \\
\text { filled spikelet }\end{array}$ \\
\hline $\mathrm{T}_{1}=$ Control & $56.67^{c}$ & 21 & 1.76 & 18.05 & $115.00^{\mathrm{a}}$ & 89.00 & $77.00^{\mathrm{b}}$ \\
\hline $\mathrm{T}_{2}=\mathrm{FFP}$ & $63.18^{\mathrm{b}}$ & 23 & 2.08 & 24.07 & $86.00^{\mathrm{b}}$ & 71.00 & $83.00^{\mathrm{ab}}$ \\
\hline $\mathrm{T}_{3}=\mathrm{STB}$ & $60.48^{b c}$ & 21 & 2.18 & 22.68 & $79.00^{\mathrm{b}}$ & 69.00 & $88.00^{\mathrm{a}}$ \\
\hline $\mathrm{T}_{4}=\mathrm{RCM}$ & $58.85^{\mathrm{bc}}$ & 22 & 2.04 & 21.80 & $82.00^{\mathrm{b}}$ & 68.00 & $83.00^{\mathrm{ab}}$ \\
\hline $\mathrm{T}_{5}=\mathrm{OF}+\mathrm{N}$ & $69.22^{\mathrm{a}}$ & 23 & 2.14 & 23.32 & $99.00^{\mathrm{ab}}$ & 78.00 & $79.00^{\mathrm{b}}$ \\
\hline
\end{tabular}

Means in a column followed by common letters are not significantly different at 5\% level of significance. FFP: Farmer's Fertilizer Practice, STB: Soil-test-based, RCM: Rice Crop Manager, OF: Organic fertilizer, OF + N: OF + Nitrogen

$P \leq 0.01)$ [Table 4]. These soil factors positively influenced plant growth of rice during the rapid tillering stage. Soil $\mathrm{pH}$ controls the soil's solubility, mobility, and bioavailability of plant nutrients [50]. At near neutral $\mathrm{pH}$, most of the macro and micronutrients (trace elements) becomes available. On the other hand, $\mathrm{K}$ is involved in various biochemical (protein synthesis, carbohydrate metabolism, and enzyme activation) and physiological processes (stomatal regulation and photosynthesis) that are responsible for plant growth and development [51]. Moreover, $\mathrm{K}$ also improves plant resistance against pest and disease infestation, metal toxicity, and drought, ultimately affecting plant growth. A similar growth improvement with manure application either applied solely or combined with chemical fertilizer was reported by Iqbal et al. [38] and Escasinas and Zamora [52]. Combined application of organic and chemical fertilizers provides a balanced mixed nutrient (macro and micronutrients) essential for plant growth and survival.

\subsubsection{Plant tillers at $45 \mathrm{DAT}$}

Table 6 shows the number of plant tillers at 45 DAT as influenced by fertilizer management practices. High grain production in rice is closely associated with tillers production. High tiller numbers produce more yields. Statistical analysis revealed no significant differences in tiller numbers with nutrient mnagement practice. Tiller number per plant varied from 21 to 25 tillers, with the lowest tiller number recorded in control and the highest in the OF treatment. On average, the tiller numbers were 23 . The average number of tillers produced by modern rice varieties ranged from 20 to 25 tillers, with $14-15$ of them become productive (produce panicles) while the remaining tillers are unproductive [53].

\subsubsection{Total panicle weight plant ${ }^{1}$ and average panicle weight of rice}

Total panicle weight plant $^{-1}$ and average panicle weight of rice are presented in Table 6 . Both of these parameters were not significantly affected by fertilizer management practices. On average, the total panicle weight and mean panicle weight plant $^{-1}$ in the FFP, RCM, $\mathrm{STB}, \mathrm{OF}+\mathrm{N}$, and sole $\mathrm{OF}$ were $23 \mathrm{~g}$ and $2 \mathrm{~g}$, respectively. These values were numerically higher compared to those in the control plants (18.05 $\mathrm{g}$ and $1.76 \mathrm{~g}$ ). In general, nutrient management practice had resulted in heavier panicle weights and a higher panicle number than those in the control plants.

\subsubsection{Total grains panicle ${ }^{-1}$ and total number of filled grains panicle $^{-1}$ of rice}

The total number of grains panicle ${ }^{-1}$ significantly varied with nutrient management practice [Table 6]. Panicle grain numbers ranged from 79 to 115 grains, with $68-89$ grains filled (productive grains). The highest number of grains counted was in control, irrespective of the weight and filled grain numbers. This was followed by sole OF and combined $\mathrm{OF}+\mathrm{N}$. On the other hand, lower panicle grain numbers were counted in the FFP, STB, and RCM treatments.

Interestingly, it was also in the control and the OF treatments where the highest percentage of unfilled grains were recorded, with $23 \%$ and $17 \%$ empty grains (data not shown). Whereas, higher filled grains percentage were recorded in the FFP, RCM, and STB treatments that received chemical fertilizer. A higher ratio of filled grains in plants treated with chemical fertilizer may be attributed to higher nutrient use efficiency and improved $\mathrm{N}$ nutrition in plants. Plants with higher filled grain percentages are more efficient in partitioning photosynthetic products (carbohydrates), resulting in higher economic yield. Contrary to our findings, Siavoshi et al. [54] reported that chemical fertilizer application resulted in higher numbers of hollow spikelets per panicle against sole organic and combined organic and chemical fertilizers. Meanwhile, $\mathrm{Xu}$ et al. [55] reported higher filled grain rate in rice treated with sole manure or manure combined with chemical fertilizer over chemical fertilizer alone.

\subsubsection{Percent filled spikelet of rice}

Fertilizer management practices significantly increased the filled spikelet percentage of rice [Table 6]. The values varied from $77 \%$ to $88 \%$, with the lowest and highest filled spikelets recorded in the control and STB, respectively. A higher but statistically comparable filled spikelets values over the control were also noted on the FFP, $\mathrm{RCM}, \mathrm{OF}+\mathrm{N}$, and sole $\mathrm{OF}$ treatments. The high percentage of filled spikelets in the STB treatment may be attributed to higher use of fertilizer N (70 kg/ha) over FFP (53 kg/ha) and RCM (60 kg/ha) as well as higher plant $\mathrm{N}$-accumulation. Correlation showed a strong positive relationship between filled-spikelet percentage and tissue $\mathrm{N}$ concentration $(\mathrm{r}=0.66 ; P \leq 0.01)$ [Table 4]. Thus, grain filling percentage increases as tissue $\mathrm{N}$ content also increases. Nitrogen in rice increases spikelet number and the number of filled spikelets, which largely determined the yield potential of a plant $[41,56,57]$. Contrary to the result of our study, Gebrekidan and Seyoum [58] observed a reduction in filled spikelets with an increasing $\mathrm{N}$. Similarly, the combined $\mathrm{P}$ with increasing $\mathrm{N}$ decreased spikelet fertility in rice [59].

\subsection{Impacts of SNM Practices on Fresh Straw Yield of Rice}

Straw yield production of rice significantly increased with fertilizer management practices [Table 7]. The plots amended with $\mathrm{OF}+\mathrm{N}$ increased straw yield by $50 \%$ over the control. Likewise, the FFP, $\mathrm{STB}$, sole $\mathrm{OF}$, and RCM treatments increased straw yield production by $48 \%, 45 \%, 35 \%$, and $27 \%$, respectively. Conversely, the lowest biomass produced was observed in control plants, which was statistically similar to the rest of the treatments, except $\mathrm{OF}+\mathrm{N}$. On 
Table 7: Means for the straw and grain yield and net income of lowland rice as affected by soil nutrient management practices

\begin{tabular}{lccccc} 
Treatments & Straw yield (t/ha) & Grain yield (t/ha) & Net income (P/ha) & Production cost (P/ha) & Gross income (P/ha) \\
$\mathrm{T}_{1}=$ Control & $10.63^{\mathrm{b}}$ & $3.78^{\mathrm{c}}$ & $33,198.00^{\mathrm{ab}}$ & $23,552.00^{\mathrm{d}}$ & $56,750.00^{\mathrm{c}}$ \\
$\mathrm{T}_{2}=$ FFP & $15.78^{\mathrm{ab}}$ & $4.62^{\mathrm{ab}}$ & $39,698.00^{\mathrm{ab}}$ & $29,552.00^{\mathrm{c}}$ & $69,250.00^{\mathrm{ab}}$ \\
$\mathrm{T}_{3}=\mathrm{STB}$ & $15.38^{\mathrm{ab}}$ & $4.95^{\mathrm{a}}$ & $41,040.00^{\mathrm{a}}$ & $33,260.00^{\mathrm{b}}$ & $74,300.00^{\mathrm{a}}$ \\
$\mathrm{T}_{4}=$ RCM & $13.53^{\mathrm{ab}}$ & $4.69^{\mathrm{ab}}$ & $38,870.00^{\mathrm{ab}}$ & $31,530.00^{\mathrm{b}}$ & $70,400.00^{\mathrm{ab}}$ \\
$\mathrm{T}_{5}=$ OF $+\mathrm{N}$ & $15.93^{\mathrm{a}}$ & $4.75^{\mathrm{ab}}$ & $35,515.00^{\mathrm{ab}}$ & $35,735.00^{\mathrm{a}}$ & $71,250.00^{\mathrm{ab}}$ \\
$\mathrm{T}_{6}=$ OF & $14.30^{\mathrm{ab}}$ & $4.35^{\mathrm{bc}}$ & $32,075.00^{\mathrm{b}}$ & $32,408.33^{\mathrm{b}}$ & $65,250.00^{\mathrm{bc}}$ \\
\hline
\end{tabular}

Means in a column followed by common letters are not significantly different at 5\% level of significance. FFP: Farmer's Fertilizer Practice, STB: Soil-test-based, RCM: Rice Crop Manager, OF: Organic fertilizer, OF + N: OF + Nitrogen

average, straw yield produced under various nutrient management practices was $15 \mathrm{t} / \mathrm{ha}$, notably higher than the unfertilized control (10. $63 \mathrm{t} / \mathrm{ha}$ ). Moreover, the mean straw yield was 3 times heavier than the grain yield produced per hectare. Correlation analysis showed a strong to very strong positive and significant relationship between straw yield production and $\mathrm{N}$ uptake $(\mathrm{r}=0.88 ; P \leq 0.01)$ and $\mathrm{K}$ uptake $(\mathrm{r}=0.64 ; P \leq 0.05)$ [Table 4]. Hence, straw yield production increases with increased $\mathrm{N}$ and $\mathrm{K}$ uptake. Furthermore, straw yield was moderately correlated with plant height $(\mathrm{r}=0.54 ; P$ $\leq 0.05$ ) [Table 4]. Thus, plants that are taller in heights were likely to produce heavier biomass. Our result concurs with Arif et al. [60] findings, who reported higher biological yield (straw yield) of rice with organic manure combined with inorganic fertilizer. Furthermore, Islam et al. [61] reported that the application of animal manure combined with chemical fertilizer notably increased the straw yield of rice.

\subsection{Impacts of SNM Practices on Grain Yield of Rice}

Nutrient management practice significantly increased grain yield production in rice [Table 7]. The highest production was recorded in the STB at $4.95 \mathrm{t} / \mathrm{ha}$. This represented a $31 \%$ increase in yield over the control. Similarly, OF+N, RCM, FFP, and sole OF increased yield by $26 \%, 24 \%, 22 \%$, and $15 \%$, respectively. Conversely, the control treatment obtained the lowest yield at $3.78 \mathrm{t} / \mathrm{ha}$, which was statistically comparable with sole OF. Higher grain yield obtained in the STB practice may be attributed to higher nutrient/fertilizer use efficiency and improved crop nutrition ( $\mathrm{N}$ and $\mathrm{K}$ ). Grain yield was strongly correlated with $\mathrm{N}$ uptake $(\mathrm{r}=0.73 ; P \leq 0.01)$ and $\mathrm{K}$ uptake $(\mathrm{r}=0.70 ; P$ $=0.01$ ) [Table 4]. The association was positive and significant. Hence, grain yield increased was directly related to the increase in $\mathrm{N}$ and $\mathrm{K}$ uptake of plants. Moreover, grain yield was strongly associated with straw yield $(\mathrm{r}=0.76 ; P \leq 0.01)$ [Table 4]. The correlation suggests that with the increase of vegetative growth, grain yield also increases. Plants that produced more tillers intercept more solar radiation resulting in higher grain yield production.

Similarly, RCM practice significantly increased grain yield of rice. This increase might be associated with higher use of fertilizer N (60 kg N/ha) and improved crop nutrient acquisition [18]. Furthermore, the superior yield obtained in STB and RCM might be attributed to better timing of fertilizer application, which resulted in higher and more efficient crop nutrient utilization. Fertilizers in the RCM and STB were split applied during tillering and panicle initiation, where nutrient demand is higher. On average, the yield obtained in the FFP, RCM, STB, sole OF, and $\mathrm{OF}+\mathrm{N}$ surpassed the mean yield in the region in 2019, which is currently at $3.20 \mathrm{t} / \mathrm{ha}$ [62]. It also surpassed the average national rice production in 2018, which is at $3.97 \mathrm{t} / \mathrm{ha}$ [63] Nutrient management practice, which undoubtedly increased soil fertility and improved crop nutrition, has contributed to higher grain production in rice. The present findings concur with the result of Sarkar et al. [49]. They reported maximum numbers of filled grains, grain, and straw yields of rice applied with STB inorganic fertilizer, solitary, or co-applied with manure. Similarly, higher grain yield with STB fertilizer application was reported by Mamun et al. [64]. Fertilizer recommendations are based on crop nutrient requirement, current soil fertility level, and target yield. Therefore, fertilizer dose applied is more precise compared to other management practices.

Moreover, in areas where organic manures are abundant and where chemical fertilizer is less accessible and expensive, the farmers may opt using combined organic and inorganic fertilizer to maximize crop yield. In the study, the OF $+\mathrm{N}$ treatment posted a $26 \%$ increase in yield over the control and had a comparable return over STB treatment. This is possible because OF combined with inorganic fertilizer may increase the fertilizer use efficiency and improve soil's physical and chemical properties. This would be the reason for increased yield [13,38]. Islam et al. [61] reported the same increase in rice grain yield with organic manure plus inorganic fertilizer application. Likewise, integrating organic and inorganic fertilizers enhanced yield and yield components of rice $[48,65]$.

\subsection{Impacts of SNM Practices on the Net Income of Rice Production}

The total gross income, production cost, and net income hectare ${ }^{-1}$ of rice are presented in Table 7 . Net income is a parameter used to measure profitability in rice production. Net income is determined by getting the difference between gross income and production costs. Total production cost includes labor (e.g., land preparation, transplanting, weeding, pesticide and fertilizer application, and harvesting), supplies, and materials (pesticide, seeds, and fertilizer). The most profitable fertilizer management practice in the study was STB, with a total net income amounting to $\mathrm{P} 41,040.00$. This represented a $24 \%$ increase in profit over the control. The second most profitable treatment was the FFP, with a net profit of $P 39,698.00$, which represented a $20 \%$ increase in profit over the control. Higher profitability observed in STB and FFP was attributed to higher grain yield and lower production cost, respectively. On the contrary, the lowest profit of $\mathrm{P}$ 32,075.00 was obtained in the sole OF treatment. The untreated control followed this with a net income of P 33,198.00. Lower profitability found in the sole OF was due to high cost of fertilizers. Meanwhile, RCM treatment had a total net profit of $\mathrm{P}$ $38,870.00$, which was higher by $17 \%$ over the control.

Moreover, rice profitability could be augmented by integrating organic manure with commercial fertilizer. The combined $\mathrm{OF}+\mathrm{N}$ obtained a comparable net income (P 35,515.00) with 
STB, despite the highest production cost incurred. The order of net income increase with nutrient management practice is as follows: $\mathrm{STB}>\mathrm{FFP}>\mathrm{RCM}+\mathrm{OF}+\mathrm{N}>\mathrm{Control}>\mathrm{OF}$. On the other hand, total production cost was observed in the order of $\mathrm{OF}+\mathrm{N}>\mathrm{STB}>\mathrm{OF}>\mathrm{RCM}>\mathrm{FFP}>$ Control. Moreover, net income had a very strong association with grain yield $(\mathrm{r}=0.92 ; P \leq 0.01)$ [Table 4]. The relationship was positive and significant. Hence, net income increased significantly with the increase in grain yield. The results from this study are consistent with what was reported by Sharma et al. [66] that superior yield and high net return in rice production were obtained with STB fertilizer recommendation against farmer's practice and general recommended fertilizer dose. Likewise, fertilizer application based on soil test values increased grain yield and net return of rice over general fertilizer recommendation [67]. Furthermore, net profit and benefit-cost ratio or rice were higher in STB fertilizer dose applied solely or co-applied with organic manure [49]. Similarly, Mamun et al. [64] reported a higher grain yield of rice with soil testbased fertilizer application and RCM. However, higher profitability was observed in the RCM compared to other fertilizer treatments due to the lower fertilizer costs.

\section{CONCLUSION}

SNM practice significantly increased soil fertility, nutrient uptake, rice productivity, and profitability. Sole $\mathrm{OF}$ and $\mathrm{OF}+\mathrm{N}$ application substantially increased soil $\mathrm{OC}$, total $\mathrm{N}$, available $\mathrm{P}$ and $\mathrm{K}$ content after harvest. Meanwhile, sole OF and STB management markedly increase the $\mathrm{N}$ and $\mathrm{K}$ uptake of rice, respectively. The maximum yield $(4.95 \mathrm{t} / \mathrm{ha})$, and net profit $(\mathrm{P} 41,040.00)$ were obtained in the STB practice. Likewise, the FFP (4.62 t/ha, P 39,698.00) and RCM (4.69 t/ha, P 38,870.00) practice attained a comparable increase in profit and yield with STB. Furthermore, combined application of organic and inorganic fertilizer boosted rice profitability and productivity. In the study, the $\mathrm{OF}+\mathrm{N}$ treatment registered a $4.75 \mathrm{t}$ / ha yield and a net income of $\mathrm{P} 35,515.00$. Conversely, lower yield and profits were obtained in control (3.78 t/ha; $\mathrm{P33}, 198.00)$ and sole OF $(4.35 \mathrm{t} / \mathrm{ha}$; $32,075.00)$ treatments. Based on the above results, STB was the most profitable and productive nutrient management practice.

\section{AUTHOR CONTRIBUTIONS}

All authors made substantial contributions to conception and design, acquisition of data, or analysis and interpretation of data; took part in drafting the article or revising it critically for important intellectual content; agreed to submit to the current journal; gave final approval of the version to be published; and agree to be accountable for all aspects of the work. All the authors are eligible to be an author as per the international committee of medical journal editors (ICMJE) requirements/guidelines.

\section{FUNDING}

There is no funding to report.

\section{CONFLICTS OF INTEREST}

The authors report no financial or any other conflicts of interest in this work.

\section{ETHICAL APPROVALS}

This study does not involve experiments on animals or human subjects.

\section{PUBLISHER'S NOTE}

This journal remains neutral with regard to jurisdictional claims in published institutional affiliation.

\section{REFERENCES}

1. PSA. Selected Statistics on Agriculture; 2018. Available from: https:// www.psa.gov.ph/sites/default/files/Selected $\% 20$ Statistics $\% 20$ on\%20Agriculture\%202018.pdf. [Last accessed on 2020 Mar 20].

2. PSA. Selected Statistics on Agriculture; 2017. Available from: https://www.psa.gov.ph/sites/default/files/SSA2017\%20\%281\%29. pdf. [Last accessed on 2020 Mar 20].

3. UC Sustainable Agriculture Research and Education Program. Soil Nutrient Management. What is Sustainable Agriculture? UC Division of Agriculture and Natural Resources; 2017. Available from: http:// www.asi.ucdavis.edu/programs/ucsarep/what-is-sustainableagriculture/practices/soil-nutrient-management. [Last accessed on 2020 Apr 25].

4. Rasoulzadeh A, Yaghoubi A. Effect of cattle manure on soil physical properties on a sandy clay loam soil in North-West Iran. J Food Agric Environ 2010;8:976-9.

5. Adeyemo AJ, Akingbola OO, Ojeniyi SO. Effects of poultry manure on soil infiltration, organic matter contents and maize performance on two contrasting degraded alfisols in South Western Nigeria. Int J Recycl Org Waste Agric 2019;8:573-80.

6. Adekiya AO, Agbede TM, Ejue WS, Aboyeji CM, Dunsin O, Aremu CO, et al. Biochar, poultry manure and NPK fertilizer: Sole and combine application effects on soil properties and ginger (Zingiber officinale Roscoe) performance in a tropical alfisol. Open Agric 2020;5:30-9.

7. Widowati W, Sutoyo S, Karamina H, Fikrinda W. Soil amendment impact to soil organic matter and physical properties on the three soil types after second corn cultivation. AIMS Agric Food 2020;5:150-68.

8. Dadashi S, Sepanlou MG, Mirnia SK. Influence organic compost compounds on soil chemical and physical properties. Int J Hum Capital Urban Manage 2019;4:15-22.

9. Ewulo BS, Ojeniyi SO, Akanni DA. Effect of poultry manure on selected soil physical and chemical properties, growth, yield and nutrient status of tomato. Afr J Agric Res 2008;3:612-6.

10. Agbede TM. Influence of five years of tillage and poultry manure application on soil properties and ginger (Ziginber officinale Roscoe) productivity. J Crop Sci Biotech 2019;22:91-9.

11. Maduka CM, Udensi CG. Comparative analysis of the effect of some organic manure on soil microorganisms. Bionatura 2019;4:1-4.

12. Mokgolo MJ, Mzezewa J, Odhiambo JJ. Poultry and cattle manure effects on sunflower performance, grain yield and selected soil properties in Limpopo Province, South Africa. S Afr J Sci 2019;115:1-7.

13. Mahmood F, Khan I, Ashraf U, Shahzad T, Hussain S, Shahid M, et al. Effects of organic and inorganic manures on maize and their residual impact on soil physico-chemical properties. J Soil Sci Plant Nutr 2017;17:22-32.

14. Islam MA, Islam S, Akter A, Rahman MH, Nandwani D. Effect of organic and inorganic fertilizers on soil properties and the growth, yield and quality of tomato in Mymensingh, Bangladesh. Agric 2017;7:1-7.

15. Mittal S, Sharma SK. Effect of different approaches of fertilizer recommendations on yield, nutrient uptake and economics of rice under SRI. J Pharmacogn Phytochem 2018;7:761-5.

16. Rajput PS, Srivastava S, Sharma BL, Sachidanand B, Dey P, Aher SB, et al. Effect of soil-test-based long-term fertilization on soil health and performance of rice crop in vertisols of Central India. Int J Agric Environ Biotechnol 2016;9:801-6. 
17. IRRI: Crop Manager; 2020. Available from: http://www.cropmanager. irri.org/home. [Last accessed on 2020 Apr 20].

18. Sharma S, Rout KK, Khanda CM, Tripathi R, Shahid M, Nayak A, et al. Field-specific nutrient management using rice crop manager decision support tool in Odisha, India. Field Crops Res 2019; 241:1-13.

19. Singh B, Singh VK. Fertilizer management in rice. In: Chauhan BS, Jabran K, Mahajan G, editors. Rice Production Worldwide. Berlin, Germany: Springer International Publishing; 2017. p. 217-53.

20. Carating RB, Galanta RG, Bacatio CD. The Soils of the Philippines. Netherlands: Springer; 2014.

21. Mishra A, Taing K, Hall MW, Shinogi Y. Effects of rice husk and rice husk charcoal on soil physicochemical properties, rice growth and yield. Agric Sci 2017;8:1014-32.

22. Azeez JO, Van Averbeke W. Nitrogen mineralization potential of three animal manures applied on a sandy clay loam soil. Bioresour Technol 2010;101:5645-51.

23. Fageria NK, Dos Santos AB, Morales MF. Influence of urea and ammonium sulfate on soil acidity indices in lowland rice production. Commun Soil Sci Plant Anal 2010;41:1565-75.

24. Philippine Council for Agriculture, Forestry and Natural Resources Research and Development. Environmental Adaptation of Crops. Book Series No. 37. Los Baños, Laguna, Philippines: Philippine Council for Agriculture, Forestry and Natural Resources Research and Development Foundation Inc.; 1986. p. 289.

25. Putra RC, Hidayah SN, Purwanto BH. Influence of goat manure and Azolla on soil properties, nitrogen use efficiency, growth and yield of organic rice farming in Indonesia. IOP Conf Ser 2018;215:1-7.

26. Tayyab M, Islam W, Arafat Y, Pang Z, Zhang C, Lin Y, et al. Effect of Sugarcane straw and goat manure on soil nutrient transformation and bacterial communities. Sustainability 2018;10:1-21.

27. Masunga RH, Uzokwe VN, Mlay PD, Odeh I, Singh A, Buchan D, et al. Nitrogen mineralization dynamics of different valuable organic amendments commonly used in agriculture. Appl Soil Ecol 2016;101:185-93.

28. Choudhury AT, Kennedy IR. Nitrogen fertilizer losses from rice soils and control of environmental pollution problems. Commun Soil Sci Plant Anal 2005;36:1625-39.

29. Cameron KC, Di HJ, Moir JL. Nitrogen losses from the soil/plant system: A review. Ann Appl Biol 2012;162:145-73

30. Uwah DF, Eyo VE. Effects of number and rate of goat manure application on soil properties, growth and yield of sweet maize (Zea mays L. Saccharata strut). Sustain Agric Res 2014;3:75-83.

31. Uwah DF, Undie LU, Nkereuwem MJ. Comparative evaluation of animal manures on soil properties, growth and yield of sweet maize (Zea mays L. Saccharata strut.). J Agric Environ Sci 2014;3:315-31.

32. Cai A, Xu H, Shao X, Zhu P, Zhang W, Xu M, et al. Carbon and nitrogen mineralization in relation to soil particle-size fractions after 32 years of chemical and manure application in a continuous maize cropping system. PLoS One 2016;11:1-14.

33. Hou E, Chen C, Wen D, Liu X. Relationships of phosphorus fractions to organic carbon content in surface soils in mature subtropical forests, Dinghushan, China. Soil Res 2014;52:55-63.

34. Ojeniyi SO, Akanni DA, Awodun MA. Effect of goat manure on some soil properties and growth, yield and nutrient status of tomato. U K J Agric Sci 2007;15:396-406.

35. Gichangi EM, Mnkeni PN, Brookes PC. Goat manure application improves phosphate fertilizer effectiveness through enhanced biological cycling of phosphorus. Soil Sci Plant Nutr 2010;56:853-60.

36. Kihanda FM, Waren GP, Micheni AN. Effects of manure application on crop yield and soil chemical properties in a long-term field trial in semi-arid Kenya. Nutr Cycl Agroecosys 2006;76:341-54.

37. Cui X, Zhang Y, Gao J, Peng F, Gao P. Long-term combined application of manure and chemical fertilizer sustained higher nutrient status and rhizospheric bacterial diversity in reddish paddy soil of Central South China. Sci Rep 2018;8:1-10.

38. Iqbal A, He L, Khan A, Wei S, Akhtar K, Ali I, et al. Organic manure coupled with inorganic fertilizer: An approach for the sustainable production of rice by improving soil properties and nitrogen use efficiency. J Agron 2019;9:1-20.

39. Campbell CR. Reference Sufficiency Ranges for Plant Analysis in the Southern Region of the United States. Southern Cooperative Series Bulletin No. 394. United States: North Carolina Department of Agriculture and Consumer Services Agronomy Division; 2009.

40. Ida M, Ohsugi R, Sasaki H, Aoki N, Yamagishi T. Contribution of nitrogen absorbed during ripening period to grain filling in a highyielding rice variety, Takanari. Plant Prod Sci 2009;12:176-84.

41. Pan SG, Huang SQ, Zhai J, Wang JP, Cao CG, Cai ML, et al. Effects of $\mathrm{N}$ management on yield and $\mathrm{N}$ uptake of rice in Central China. J Integr Agric 2012;11:1993-2000.

42. Nutrient Management: Nitrogen; 2020. Available from: http://www. knowledgebank.irri.org/training/fact-sheets/nutrient-management/ item/nitrogen. [Last accessed on 2020 Mar 06].

43. Djaman K, Mel VC, Ametonou FY, El-Namaky R, Diallo MD, Koudahe K. Effect of nitrogen fertilizer dose and application timing on yield and nitrogen use efficiency of irrigated hybrid rice under semi-arid conditions. J Agric Sci Food Res 2018;9:1-7.

44. Yesuf E, Balcha A. Effect of nitrogen application on grain yield and nitrogen efficiency of Rice (Oryza sativa L.). Asian J Crop Sci 2014;6:273-80.

45. Nutrient Management: Potassium; 2020. Available from: http://www. knowledgebank.irri.org/training/fact-sheets/nutrient-management/ item/potassium-k. [Last accessed on 2020 Mar 06].

46. Islam A, Chandrabiswas J, Karim AJ, Salmapervin MS, Saleque MD. Effects of potassium fertilization on growth and yield of wetland rice in grey terrace soils of Bangladesh. Res Crop Ecophysiol 2015; 10:64-82.

47. Banerjee H, Ray K, Dutta SK, Majumdar K, Satyanarayana T, Timsina J. Optimizing potassium application for hybrid rice (Oryza sativa L.) in coastal saline soils of West Bengal, India. Agronomy 2018;8:1-14.

48. Moe K, Moh SM, Htwe AZ, Thu TT, Kajihara Y, Yamakawa T. Effects of integrated organic and inorganic fertilizers on yield and growth parameters of rice varieties. Rice Sci 2019;26:309-18.

49. Sarkar MI, Rahman MM, Rahman GK, Naher UA, Ahmed MN. Soil test based inorganic fertilizer and integrated plant nutrition system for rice (Oryza sativa L.) cultivation in inceptisols of Bangladesh. Agriculturists 2016;14:33-42.

50. Neina D. The role of soil $\mathrm{pH}$ in plant nutrition and soil remediation. Appl Environ Soil Sci 2019;8:1-9.

51. Hasanuzzaman M, Bhuyan MH, Nahar K, Hossain MS, Al Mahmud J, Hossen MS, et al. Potassium: A vital regulator of plant response and tolerance to abiotic stresses. Agronomy 2018;31:1-29.

52. Escasinas RO, Zamora OB. Agronomic response of lowland rice PSB Rc 18 (Oryza sativa L.) to different water, spacing and nutrient management. Philipp J Crop Sci 2011;36:37-46.

53. Pawar SY, Radhakrishnan VV, Mohanan KV. The importance of optimum tillering in rice-an overview. South Indian J Biol Sci 2016;2:125-7.

54. Siavoshi M, Nasiri A, Laware SL. Effect of organic fertilizer on growth and yield components in rice (Oryza sativa L.). J Agric Sci 2011;3:217-24.

55. Xu MG, Li DC, Li JM, Qin DZ, Kazuyuki Y, Yasukazu H. Effects of organic manure application with chemical fertilizers on nutrient absorption and yield of rice in Hunan of Southern China. Agric Sci China 2008;7:1245-52.

56. Kamara AY, Ekeleme F, Omoigui LO, Chikoye D. Influence of nitrogen fertilization on yield and yield components of rain-fed 
lowland NERICA rice in the Northern Guinea savanna of Nigeria. Afr J Agric Res 2011;6:3092-7.

57. Ullah SS, Amin AK, Roy TS, Mandal MS, Mehraj H. Effect of nitrogen sources for spikelet sterility and yield of Boro rice varieties. Adv Plants Agric Res 2016;5:1-10.

58. Gebrekidan H, Seyoum M. Effects of mineral N and P fertilizers on yield and yield components of flooded lowland rice on vertisols of Fogera. J Agric Rural Dev Trop 2006;107:161-76.

59. Djaman K, Bado BV, Mel VC. Effect of nitrogen fertilizer on yield and nitrogen use efficiency of four aromatic rice varieties. Emir $\mathrm{J}$ Food Agric 2016;28:126-35.

60. Arif M, Tasneem M, Bashir F, Yaseen G, Iqbal RM. Effect of integrated use of organic manures and inorganic fertilizers on yield and yield components of rice. J Agric Res 2014;52:197-206.

61. Islam MM, Khan MA, Bari AS, Hosain MT, Sabikunnaher M. Effect of fertilizer and manure on the growth, yield and grain nutrient concentration of Boro rice (Oryza sativa L.) under different water management practices. Agriculturists 2013;11:44-51.

62. National Economic and Development Authority. CARAGA $3^{\text {rd }}$ Quarter 2019: Regional Economic Situationer; 2019. Available from: http://www.nro13.neda.gov.ph/wp-content/uploads/2020/02/ QRES_3Q_2019-FINAL.pdf. [Last accessed on 2020 Apr 20].

63. PSA. Selected Statistics on Agriculture; 2019. Available from: https://
www.psa.gov.ph/sites/default/files/Selected $\% 20$ Statistics $\% 20$ on\%20Agriculture\%202019.pdf. [Last accessed on 2020 Apr 20].

64. Mamun MA, Haque MM, Saleque MA, Khaliq QA, Karim AJ, Karim MA. Evaluation of different fertilizer management guidelines for Boro rice cultivation in South Central coastal region of Bangladesh. Ann Agric Sci 2018;5:1-10.

65. Amanullah J, Hidayatullah K. Influence of organic and inorganic nitrogen on grain yield and yield components of hybrid rice in North Western Pakistan. Rice Sci 2016;23:326-33.

66. Sharma GK, Mishra VN, Sankar GR, Patil SK, Srivastava LK, Thakur $\mathrm{SD}$, et al. Soil-test-based optimum fertilizer doses for attaining yield targets of rice under midland alfisols of Eastern India. Commun Soil Sci Plant Anal 2015;46:2177-90.

67. Sharma SH, Srilatha M, Shankar M, Ramulu C. Response of paddy to soil test-based fertilizer application for targeted yield. Prog Res 2014;9:1129-33.

\section{How to cite this article: \\ Rollon RJC, Golis JM, Salas E. Impacts of soil nutrient management practices on soil fertility, nutrient uptake, rice (Oryza sativa L.) productivity, and profitability. J App Biol Biotech. 2021;9(2):75-84.}

DOI: 10.7324/JABB.2021.9207 